\title{
Molecular survey of neglected bacterial pathogens reveals an abundant diversity of species and genotypes in ticks collected from animal hosts across Romania
}

Martin O. Andersson ${ }^{1}$, Conny Tolf ${ }^{1}$, Paula Tamba², Mircea Stefanache ${ }^{3}$, Gabriel Radbea ${ }^{4}$, Dimitrios Frangoulidis ${ }^{5}$, Herbert Tomaso ${ }^{6}$, Jonas Waldenström¹ ${ }^{1}$ Gerhard Dobler ${ }^{5,7^{*}}$ and Lidia Chitimia-Dobler $2,5,7$

\begin{abstract}
Background: Ticks are transmitting a wide range of bacterial pathogens that cause substantial morbidity and mortality in domestic animals. The full pathogen burden transmitted by tick vectors is incompletely studied in many geographical areas, and extensive studies are required to fully understand the diversity and distribution of pathogens transmitted by ticks.

Results: We sampled 824 ticks of 11 species collected in 19 counties in Romania. Ticks were collected mainly from dogs, but also from other domestic and wild animals, and were subjected to molecular screening for pathogens. Rickettsia spp. was the most commonly detected pathogen, occurring in 10.6\% (87/824) of ticks. Several species were detected: Rickettsia helvetica, R. raoultii, R. massiliae, R. monacensis, R. slovaca and R. aeschlimannii. A single occurrence of the zoonotic bacterium Bartonella vinsonii berkhoffii was detected in a tick collected from a dog. Anaplasma phagocytophilum occurred in four samples, and sequences similar to Anaplasma marginale/ovis were abundant in ticks from ruminants. In addition, molecular screening showed that ticks from dogs were carrying an Ehrlichia species identical to the HF strain as well as the enigmatic zoonotic pathogen "Candidatus Neoehrlichia mikurensis". An organism similar to E. chaffeensis or E. muris was detected in an lxodes ricinus collected from a fox. Conclusions: We describe an abundant diversity of bacterial tick-borne pathogens in ticks collected from animal hosts in Romania, both on the level of species and genotypes/strains within these species. Several findings were novel for Romania, including Bartonella vinsonii subsp. berkhoffii that causes bacteremia and endocarditis in dogs. "Candidatus Neoehrlichia mikurensis" was detected in a tick collected from a dog. Previously, a single case of infection in a dog was diagnosed in Germany. The results warrant further studies on the consequences of tickborne pathogens in domestic animals in Romania.
\end{abstract}

Keywords: Ticks, Neglected bacterial pathogens, Animal hosts, Romania

\footnotetext{
* Correspondence: gerharddobler@msn.com

${ }^{5}$ Bundeswehr Institute of Microbiology, Neuherbergstrasse 11, D-80937

Munich, Germany

${ }^{7}$ German Center of Infection Research (DZIF) Partner Munich,

Neuherbergstrasse 11, D-80937 Munich, Germany

Full list of author information is available at the end of the article
} 


\section{Background}

Domestic animals often live in intimate contact with humans, and it has been demonstrated that pet ownership significantly increases the risk of tick encounters for their owners [1]. Thus, dogs and other domestic animals may serve as sentinels for human tick-borne diseases, and, furthermore, might even constitute a potential reservoir for zoonotic pathogens [2, 3]. Among arthropods, ticks have pivotal role as vectors for many zoonotic pathogens. A large proportion of tick-borne pathogens are bacterial. Nevertheless, several tick-borne or proposed tick-borne bacterial pathogens are not comprehensively studied and their geographical distribution is insufficiently known.

For example, the spotted-fever group rickettsiae are a diverse group of alpha-proteobacteria, exclusively associated with arthropods, which may act as vectors or reservoirs in the life-cycles of these bacteria [4]. Rickettsia may cause febrile disease in humans, and some species also in dogs, with symptoms that range from mild to lifethreatening [5]. More than 20 species with pathogenic potential for humans are described, and further species and subspecies have been proposed [6]. Rickettsia spp. are transmitted by ticks both transovarially, from the female tick to her offspring, without the need of a vertebrate reservoir, and transstadially, from a previous life stage, thereby requiring a vertebrate host to infect the previous life stage [4]. Consequently, the occurrence of transovarial transmission results in tick-borne pathogens that can be maintained in the tick population even in the (short-term) absence of vertebrate reservoirs. Also, other species within the alpha-proteobacteria are zoonotic pathogens of importance. The family Anaplasmataceae contains several species of zoonotic concern. For example, Anaplasma phagocytophilum infects humans and dogs, as well as a wide range of other domestic and wild animals [7, 8] and is known from Romania [9-11]. Other Anaplasmataceae species, such as Ehrlicia canis, A. platys and "Candidatus Neoehrlichia mikurensis", are in a few cases reported to occur in Romania [12-14], but the geographical distribution of these pathogens are not well known. Furthermore, several Bartonella spp. are pathogens in domestic animals that cause emerging diseases in humans $[3,15,16]$, the distribution of Bartonella spp. are not known in Romania. Other neglected bacteria of interest from a zoonotic tickborne disease perspective include Francisella tularensis and Coxiella spp. In order to further advance the knowledge regarding bacterial pathogens with zoonotic potential in Romania, we used molecular methods to screen ticks collected from animal hosts for the following pathogens: Rickettsia spp., Bartonella spp., Anaplasma spp., Ehrlichia spp., "Ca. Neoehrlichia mikurensis", Francisella spp. and Coxiella spp.

\section{Methods}

\section{Tick collection and identification}

Ticks were sampled from March 2014 to August 2015 in the following counties in Romania: Alba, Ilfov, Calarasi, Covasna, Dolj, Giurgiu, Gorj, Dambovita, Braila, Brasov, Mehedinti, Olt, Prahova, Timis, Salaj, Satu Mare, Sibiu, Suceava and Vilcea (Fig. 1). Ticks were collected mostly from pet dogs $(n=545)$ and few kennel or stray dogs, but also from other animals such as foxes from the rabies vaccination control program $(n=56)$, cats $(n=23)$, sheep $(n=75)$, rabbits $(n=5)$, cattle $(n=36)$, goats $(n=50)$, horses $(n=2)$ and turkey $(n=1)$. Additional questing ticks were collected from vegetation $(n=31)$ by flagging. Collected ticks were kept alive or preserved in ethanol and were identified to the taxonomic level of species using phenotypic keys $[17,18]$. Some specimens were also genetically characterized as described in [19].

\section{Nucleic acid extraction and PCR}

Ticks were homogenized using $200 \mu \mathrm{l}$ Bio101 tissue lyser. Total nucleic acid was extracted using the MagNA Pure LC RNA/DNA Kit (Roche, Mannheim, Germany) in a MagNA Pure LC instrument (Roche, Mannheim, Germany) according to the manufacturer's instructions. The total nucleic acid was stored at $-80{ }^{\circ} \mathrm{C}$ until use. Most ticks were processed individually. However, a smaller number of nymphs were pooled in groups of ten (eight pools) and three (three pools).

Detection of Rickettsia spp. was performed using a previously published real-time PCR assay targeting a part of the gltA gene [20]. For species identification of Rickettsia an assay targeting the $23 S$ intergenic spacer region was utilized, and the amplicons were sequenced, as previously described [21]. Detection of Anaplasma spp., Ehrlichia spp. and "Candidatus Neoehrlichia mikurensis" was performed with a real-time PCR assay that amplifies a part of the $16 S$ rRNA gene as described [22]. All positive amplicons obtained with this assay were purified and sequenced, using the forward primer, as described in Andersson et al. [23]. Obtained sequences were compared with published GenBank sequences using Basic Local Alignment Search Tool (BLAST) analysis. Amplification of Bartonella spp. was performed using a real-time PCR assay targeting a region of the $s s r A$-gene with primers and time/temperature profile according to Diaz et al. [24]. The DNA extracts of all ticks were further screened for the presence of Francisella spp. DNA, using a real-time PCR assay targeting the tul4 gene as described previously [25]. Finally, all samples were tested for the occurrence of Coxiella burnetii and Coxiella-like organisms using realtime PCRs for the target genes IS1111, icd and com1 as described previously [26, 27]. Details regarding target species, amplified DNA fragment, positive control used in PCR and references are given in Table 1. 


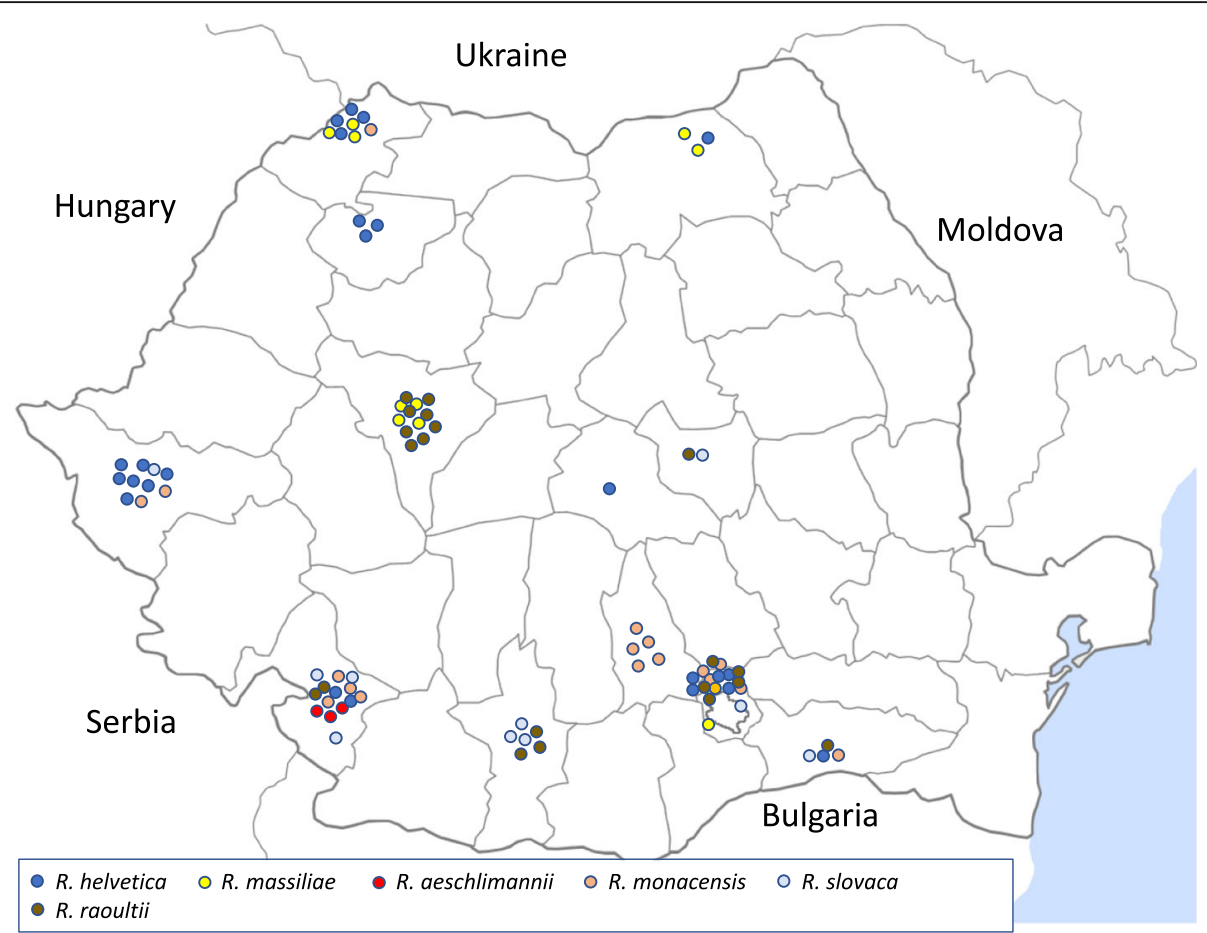

Fig. 1 Geographical distribution of Rickettsia spp. in ticks collected from animals in Romania

\section{Results}

In total, 824 ticks from 19 different counties were collected and screened for the presence of bacterial pathogens. Eleven tick species were identified: Ixodes ricinus ( $n=209: 21$ nymphs, 39 males, 149 females); Ixodes crenulatus ( $n=7: 3$ nymphs, 4 females); Dermacentor marginatus ( $n=92: 7$ nymphs, 30 males, 55 females); Dermacentor reticulatus ( $n=119: 45$ males, 74 females); Haemaphysalis punctata ( $n=38: 29$ nymphs, 9 females);
Haemaphysalis concinna ( $n=3: 1$ nymph, 2 females); Rhipicephalus sanguineus "southeastern lineage" $(n=$ 314: 143 nymphs, 64 males, 107 females); Rhipicephalus rossicus ( $n=1$ female); Rhipicephalus bursa ( $n=15: 2$ nymphs, 3 males, 10 females); Hyalomma marginatum ( $n=26: 17$ males, 9 females) and one Hyalomma scupense. Details about tick species and occurrence of respective pathogens are presented in Table 1 . Males and females and nymphs were found to carry infections but

Table 1 Details regarding target species, amplified DNA fragment, positive control used in PCR and references

\begin{tabular}{|c|c|c|c|c|}
\hline Target species & $\begin{array}{l}\text { Target } \\
\text { sequence }\end{array}$ & $\begin{array}{l}\left.\text { Primer sequences ( } 5^{\prime}-3^{\prime}\right) \text {; forward, reverse and, where } \\
\text { applicable, probe }\end{array}$ & Positive control & Reference \\
\hline Rickettsia spp. & $g / t A$ & $\begin{array}{l}\text { for: ATAGGACAACCGTTATT; } \\
\text { rev: CAAACATCATATGCAGAAA; } \\
\text { probe: FAM-CCTGATAATTCGTTAGATTTACCG-TMR }\end{array}$ & $\begin{array}{l}\text { DNA extract from positive cell culture } \\
\text { of } R \text {. monacensis (own isolate) }\end{array}$ & [20] \\
\hline $\begin{array}{l}\text { Anaplasma spp.; Ehrlichia } \\
\text { spp.; "Ca. N. mikurensis" }\end{array}$ & $16 \mathrm{~S}$ rRNA & $\begin{array}{l}\text { for: GGGGATGATGTCAARTCAGCAY; } \\
\text { rev: CACCAGCTTCGAGTTAAGCCAAT }\end{array}$ & $\begin{array}{l}\text { DNA-extract from an A. phagocytophilum- } \\
\text { positive I. ricinus }\end{array}$ & {$[22]$} \\
\hline Bartonella spp. & $s s r A$ & $\begin{array}{l}\text { for: CTATGGTAATAAATGGACAATGAAATAA; } \\
\text { rev: GCTTCTGTTGCCAGGTG }\end{array}$ & $\begin{array}{l}\text { DNA-extract from B. grahamii- positive } \\
\text { rodent blood }\end{array}$ & [24] \\
\hline Francisella spp. & tul4 & $\begin{array}{l}\text { for: ATTACAATGGCAGGCTCCAGA; } \\
\text { rev: TGCCCAAGTITTATCGTTCTTCT; } \\
\text { probe: FAM- } \\
\text { TTCTAAGTGCCATGATACAAGCTTCCCAATTACTAAG-BBQ }\end{array}$ & $\begin{array}{l}\text { Francisella tularensis holarctica Live } \\
\text { Vaccine Strain (LVS = ATCC } 29684\end{array}$ & [25] \\
\hline Coxiella spp. & $\begin{array}{l}\text { Is111, icd, } \\
\text { comi }\end{array}$ & $\begin{array}{l}\text { IS1-for: CB_A2k: TCACATTGCCGCGTTTACT; } \\
\text { IS1-rev: CBA_2k: TCACATTGCCGCGTTTACT; } \\
\text { IS1-probe: Red640-TAATCACCAATCGCTTCGTCCCGGT; } \\
\text { icdtrg_f: CGGAGTTAACCGGAGTATCCA; } \\
\text { icdtrg_r: CCGTGAATTCATGATGTTACCTI; } \\
\text { comtrg_f: CCCTGCAATTGGAACGAAG; } \\
\text { comtrg_r: GTTCTGATAATTGGCCGTCGACA }\end{array}$ & $\begin{array}{l}\text { DNA extract from cell cultured reference } \\
\text { strain NineMile RSA } 493\end{array}$ & {$[26,27]$} \\
\hline
\end{tabular}


none of the 11 pooled nymphs (eight pools with 10 nymphs/pool and three pools with 3 nymphs/pool) were positive for any pathogen. Geographical distributions of detected bacteria are shown in Figs. 1 and 2, Table 2, and Additional file 1: Table S1.

\section{Rickettsia spp.}

In total, $10.6 \%(87 / 824)$ of the tick samples were positive, by means of real-time PCR, for Rickettsia spp. Positive samples were assigned to species level by sequencing of the $23 \mathrm{~S}$ ribosomal gene. The phylogenetic relationships for the obtained Rickettsia species are depicted in Fig. 3. The most common Rickettsia spp. was $R$. raoultii, which was detected in 2.5\% (21/824) of the samples. Two different genotypes occurred, that differ by a $60 \mathrm{bp}$ insertion/deletion. The most common genotype occurred in 14/21 samples (published in GenBank with the accession number MG450326). The sequence from this genotype did not completely match any previously published sequence in GenBank. However, it was highly similar (99.7\% homology, 339/340 bp) to $R$. raoultii strain Khabarovsk (GenBank: CP010969), and similar (99.1\% homology) to $R$. raoultii strain IM16 (GenBank: CP019435). Another $R$. raoultii genotype, with $100 \%$ homology to $R$. raoultii samples from $I$. ricinus in Austria (GenBank: KX161769) was detected in seven samples.
The sequences from ten samples showed 100\% homology (339/339 bp) to Rickettsia massiliae isolate G266 (GenBank: KX506778). In 24 samples, sequences showing 100\% homology to published $R$. helvetica sequences (GenBank: JQ796866 and EU057990) occurred (486/486 bp), collected from I. ricinus in Poland and Austria, respectively. Rickettsia monacensis was detected in 18 samples. Two different $R$. monacensis genotypes occurred. The most common genotype occurred in 17 samples, and the sequences were identical to each other and showed $100 \%$ similarity to $R$. monacensis isolate SzPK2-09 (GenBank: JQ796867). A second genotype was present in a single sample, and differed at two nucleotide positions. This sequence did not match any previously published sequence in GenBank. The closest match was the $R$. monacensis strain IrR/Munich, (GenBank: LN794217; 99.4\% pairwise identity, 339/341 bp). Furthermore, 10 sequences were identical (341/341 bp) to several published $R$. slovaca sequences, for example $R$. slovaca strain D-CWPP (GenBank: CP003375). Finally, three 23S sequences were identical (335/335 bp) to $R$. aeschlimannii strain MC16 (GenBank: AY125016). From a single sample that was positive with the Rickettsia spp. real-time PCR we did not manage to obtain any readable sequences and the species could therefore not be determined. The Rickettsia spp. sequences obtained in this study have been deposited in GenBank with the following accession numbers: $R$. raoultii (MG450326 and MG450327); $R$. massiliae (MG450328); R. helvetica (MG450329); R. monacensis

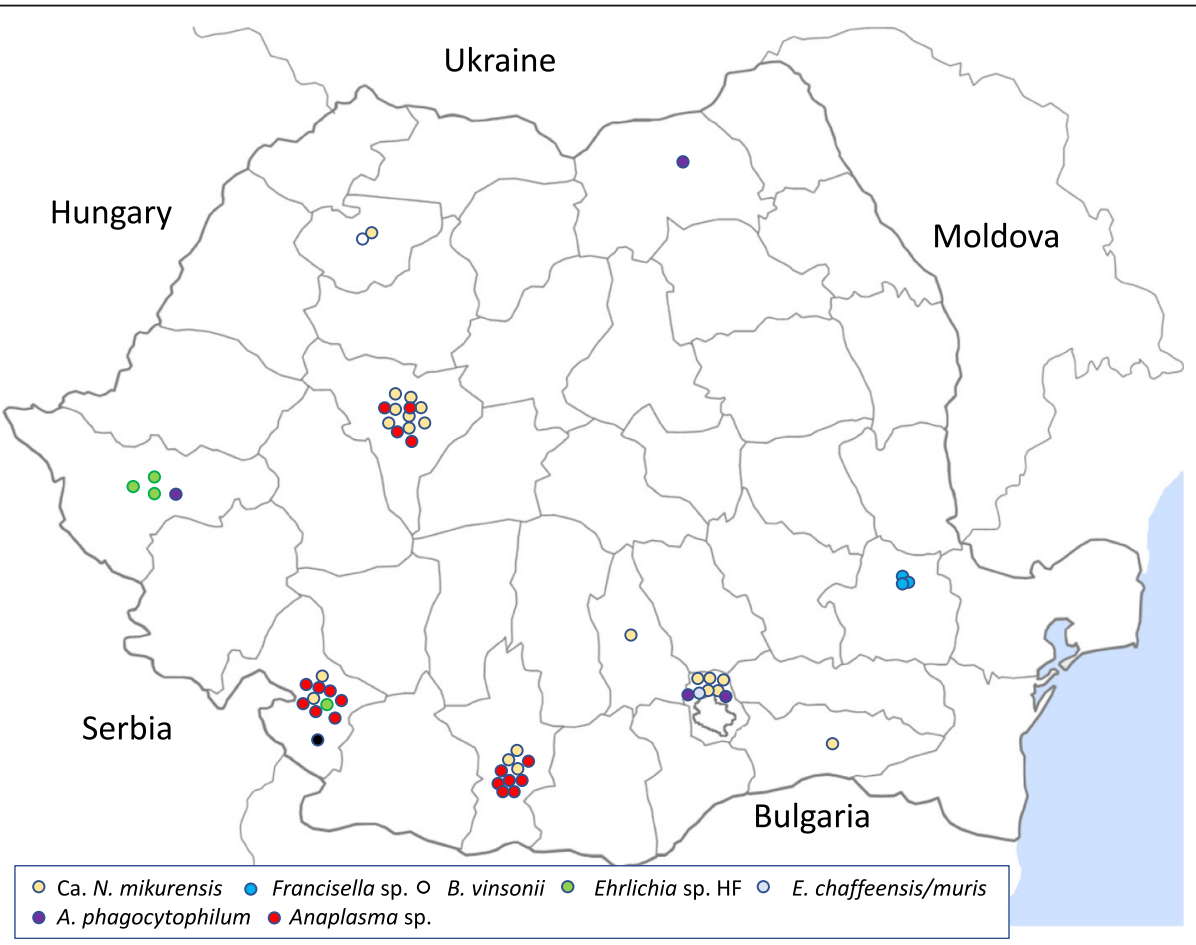

Fig. 2 Geographical distribution of "Candidatus Neoehrlichia mikurensis", Francisella sp., Bartonella vinsonii berkhoffii, Ehrlichia sp. HF, Ehrlichia chaffeensis/muris, Anaplasma phagocytophilum and Anaplasma sp. species in ticks collected from animals in Romania 
Table 2 Tick-borne bacteria in Romanian ticks; details regarding host species, tick species, life stage of ticks and area for each pathogen

\begin{tabular}{|c|c|c|c|c|}
\hline Pathogen & Host & Tick species & Tick stage & Area \\
\hline $\begin{array}{l}\text { Bartonella vinsonii berkhoffii } \\
(n=1)\end{array}$ & dog & Dermacentor reticulatus & female & Zalau \\
\hline $\begin{array}{l}\text { Rickettsia helvetica } \\
(n=24)\end{array}$ & $\begin{array}{l}\text { dog, fox, sheep, } \\
\text { cat }\end{array}$ & $\begin{array}{l}\text { Dermacentor reticulatus, Ixodes } \\
\text { ricinus, Rhipicephalus sanguineusa } \\
\text { Ixodes crenulatus }\end{array}$ & female, male, nymph & $\begin{array}{l}\text { Satu Mare, Brasov, Zalau, } \\
\text { Calarasi, Corbeanca, Timisoara, } \\
\text { Suceava, Jirov }\end{array}$ \\
\hline $\begin{array}{l}\text { Rickettsia raoultii } \\
(n=21)\end{array}$ & dog, sheep, goat & $\begin{array}{l}\text { Dermacentor reticulatus, Rhipicephalus } \\
\text { sanguineus, Dermacentor marginatus }\end{array}$ & female, male, nymph & $\begin{array}{l}\text { Snagov, Calarasi, Sfantul } \\
\text { Gheorghe, Targoviste, Livezile, } \\
\text { Snagov, Jirov, Slatioara }\end{array}$ \\
\hline $\begin{array}{l}\text { Rickettsia massiliae } \\
(n=10)\end{array}$ & dog, fox & Dermacentor reticulatus & female, male & $\begin{array}{l}\text { Satu Mare, Popesti Leordeni, } \\
\text { Alba Iulia, Suceava }\end{array}$ \\
\hline $\begin{array}{l}\text { Rickettsia monacensis } \\
(n=18)\end{array}$ & dog, fox, cat & $\begin{array}{l}\text { Dermacentor reticulatus, Rhipicephalus } \\
\text { sanguineus, Ixodes ricinus }\end{array}$ & female, male, nymph & $\begin{array}{l}\text { Satu Mare, Calarasi, Corbeanca, } \\
\text { Timisoara, Targoviste, Picior de } \\
\text { Munte, Jirov, Comanda }\end{array}$ \\
\hline $\begin{array}{l}\text { Rickettsia slovaca } \\
(n=10)\end{array}$ & $\begin{array}{l}\text { dog, fox, sheep, } \\
\text { goat, field }\end{array}$ & $\begin{array}{l}\text { Rhipicephalus sanguineus, Ixodes ricinus, } \\
\text { Dermacentor marginatus }\end{array}$ & female, male, nymph & $\begin{array}{l}\text { Calarasi, Corbeanca, Sfantul } \\
\text { Gheorghe, Timisoara, Jirov, } \\
\text { Slatioara, Starmina }\end{array}$ \\
\hline $\begin{array}{l}\text { Rickettsia aeschlimannii } \\
(n=3)\end{array}$ & cattle & Hyalomma marginatum & female, male & Livezile \\
\hline $\begin{array}{l}\text { "Ca. Neoehrlichia mikurensis" } \\
(n=1)\end{array}$ & dog & Ixodes ricinus & female & Zalau \\
\hline $\begin{array}{l}\text { Anaplasma phagocytophilum } \\
(n=4)\end{array}$ & fox, dog, sheep & Ixodes ricinus & female, male, nymph & Corbeanca, Timisoara, Suceava \\
\hline $\begin{array}{l}\text { Anaplasma marginale/ovis } \\
(n=16)\end{array}$ & $\begin{array}{l}\text { cattle, sheep, dog, } \\
\text { goat }\end{array}$ & $\begin{array}{l}\text { Rhipicephalus bursa, Dermacentor } \\
\text { marginatus, Ixodes ricinus, } \\
\text { Dermacentor reticulatus }\end{array}$ & female, male & Livezile, Ciochiuta, Jirov, Slatioara \\
\hline $\begin{array}{l}\text { Ehrlichia chaffeensis/muris } \\
(n=1)\end{array}$ & fox & Ixodes ricinus & female & Corbeanca \\
\hline $\begin{array}{l}\text { Ehrlichia sp. HF } \\
(n=4)\end{array}$ & dog & $\begin{array}{l}\text { Ixodes ricinus, Rhipicephalus } \\
\text { sanguineus }\end{array}$ & female, male & Timisoara, Jirov \\
\hline $\begin{array}{l}\text { Francisella spp. } \\
(n=3)\end{array}$ & dog & Rhipicephalus sanguineus & female & Braila \\
\hline
\end{tabular}

${ }^{\text {a }}$ Rhipicephalus sanguineus "southeastern lineage"

(MG450330 and MG450331); R. slovaca (MG450332); and R. aeschlimannii (MG450333).

\section{Bartonella spp.}

A single I. ricinus tick collected from a dog in Zalau, Salaj County, north-western Romania was positive for Bartonella spp. by means of real-time PCR. Sequencing of the amplicon demonstrated $100 \%$ homology (225/225 bp) to $B$. vinsonii berkhoffii str. Winnie. The obtained sequence has been deposited in GenBank with the accession number MG432827.

\section{Anaplasma spp., Ehrlichia spp. and "Ca. N. mikurensis"} The amplicons of all samples positive with the $16 \mathrm{~S}$ rRNA assay were successfully sequenced. The phylogenetic relationship for the sequences obtained is depicted in Fig. 4. In four cases, the obtained sequences revealed 100\% homology to published Anaplasma phagocytophilum sequences, for example the Webster strain with GenBank accession number NR_044762.1 (188/188 bp). All four samples were from I. ricinus collected from two foxes, a dog and a sheep. Sixteen sequences showed 100\% homology to published $A$. marginale and $A$. ovis sequences, while differing from published $A$. centrale sequences at two nucleotide positions. The sequences from four samples detected in three $I$. ricinus and one $R h$. sanguineus "southeastern lineage", all obtained from dogs, showed $100 \%$ pairwise similarity (187/187 bp) to Ehrlichia sp. HF obtained from I. ricinus in Brittany, France (GenBank: DQ647318), as well as Ehrlichia sp. HF obtained from $I$. ovatus collected in Japan (GenBank: AB024928). An identical sequence has been reported from I. apronophorus in Romania (GenBank: KY851781). One sequence obtained from an I. ricinus collected from a dog in Zalau, Salaj County showed $100 \%$ pairwise similarity (171/171 bp) to published sequences of "Candidatus $\mathrm{N}$. mikurensis" from various countries, for example sequences AB196305 and EU810404 from Japan and Germany, respectively.

A single organism closely related to E. chaffeensis was detected in an I. ricinus tick collected from a fox. This 


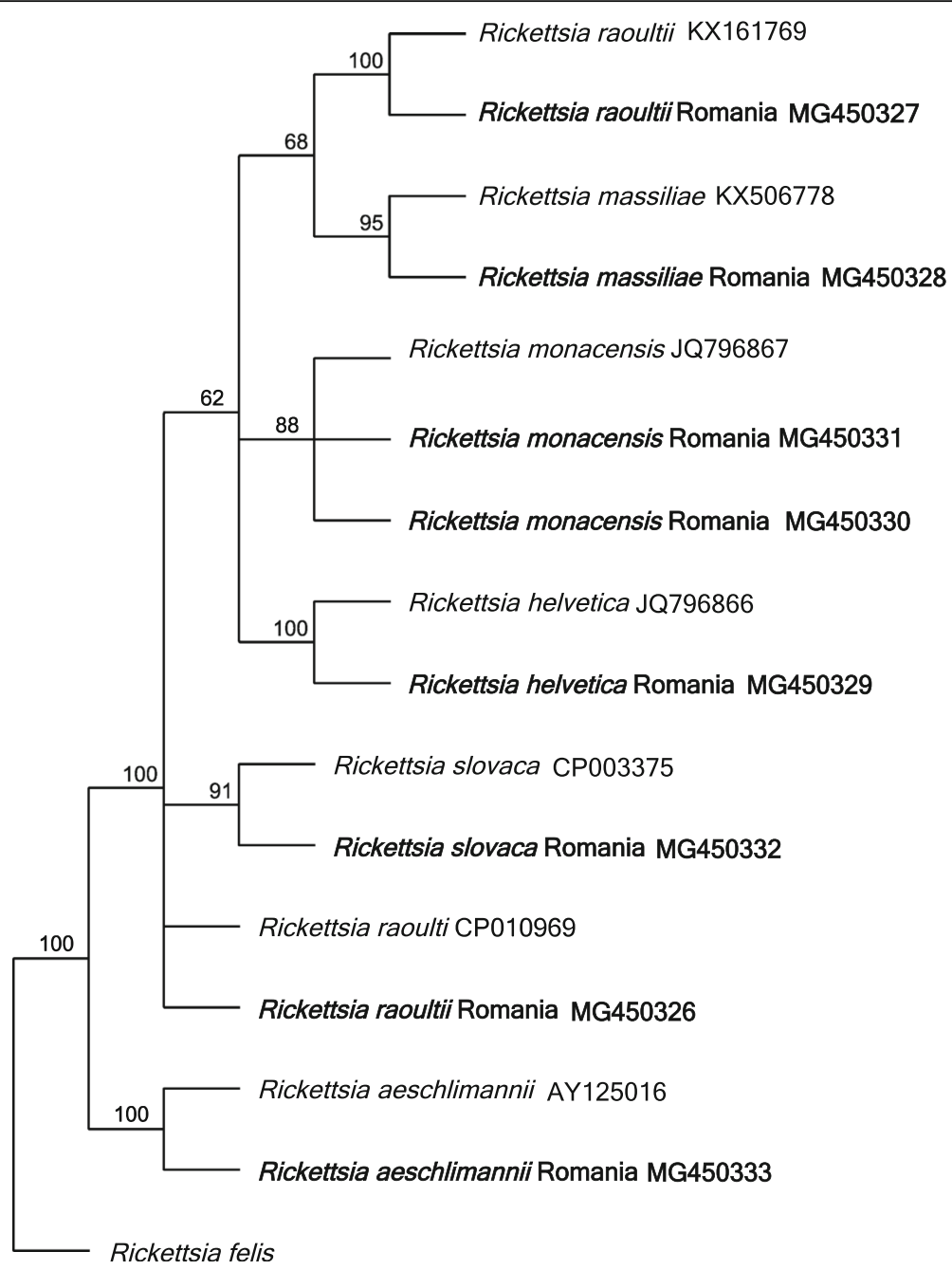

Fig. 3 Phylogenetic relationships between Rickettsia species. Neighbor-joining tree with Jukes-Cantor as genetic distance model. Sequences obtained in the current study are in bold. The tree is based on 249 nucleotide positions of the 23S-5S ribosomal RNA gene

sequence was identical to the $E$. chaffeensis reference sequence NR_037059.1 (186/186 bp), however also to the E. muris reference sequence NR_121714.1, while differing from the $E$. canis $16 S$ rRNA reference sequence NR_118741.1 at three nucleotide positions.

\section{Francisella spp. and Coxiella spp.}

Three Rh. sanguineus "southeastern lineage" females, collected from dogs of a pound in Braila, were positive for Francisella spp. by means of real-time PCR, but due to the low amount of DNA it could not be further investigated by sequencing. All tested specimens were negative for Coxiella spp. by PCR.

\section{Discussion}

We describe an abundant diversity of bacterial tick-borne pathogens in Romania. Previously, unidentified species, such as Bartonella vinsonii berkhoffii and Francisella spp., were detected as well as a diversity of genotypes within Rickettsiaceae and several Anaplasmataceae species. The most commonly detected pathogen in the current study was Rickettsia spp., occurring in over $10 \%$ of the ticks, distributed across the country and in several tick species. The following species were detected: $R$. raoultii, $R$. slovaca, $R$. helvetica, $R$. monacensis, $R$. massiliae and $R$. aeschlimannii, as well as different genotypes within some of these species. Rickettsiae are exclusively associated with arthropod vectors. For example, it is known that $D$. marginatus ticks are the main vector of $R$. slovaca and that $I$. ricinus ticks are the main vector of $R$. helvetica $[5,28,29]$. Rickettsia slovaca has also been detected in $D$. reticulatus ticks $[5,30]$. In Europe, there are numerous reports on the prevalence of zoonotic rickettsiae in $D$. reticulatus, mainly on the causative agents of tick-borne lymphadenopathy (TIBOLA), e.g. R. raoultii and $R$. slovaca [31-33]. Dermacentor reticulatus is also known as a carrier of $R$. raoultii 


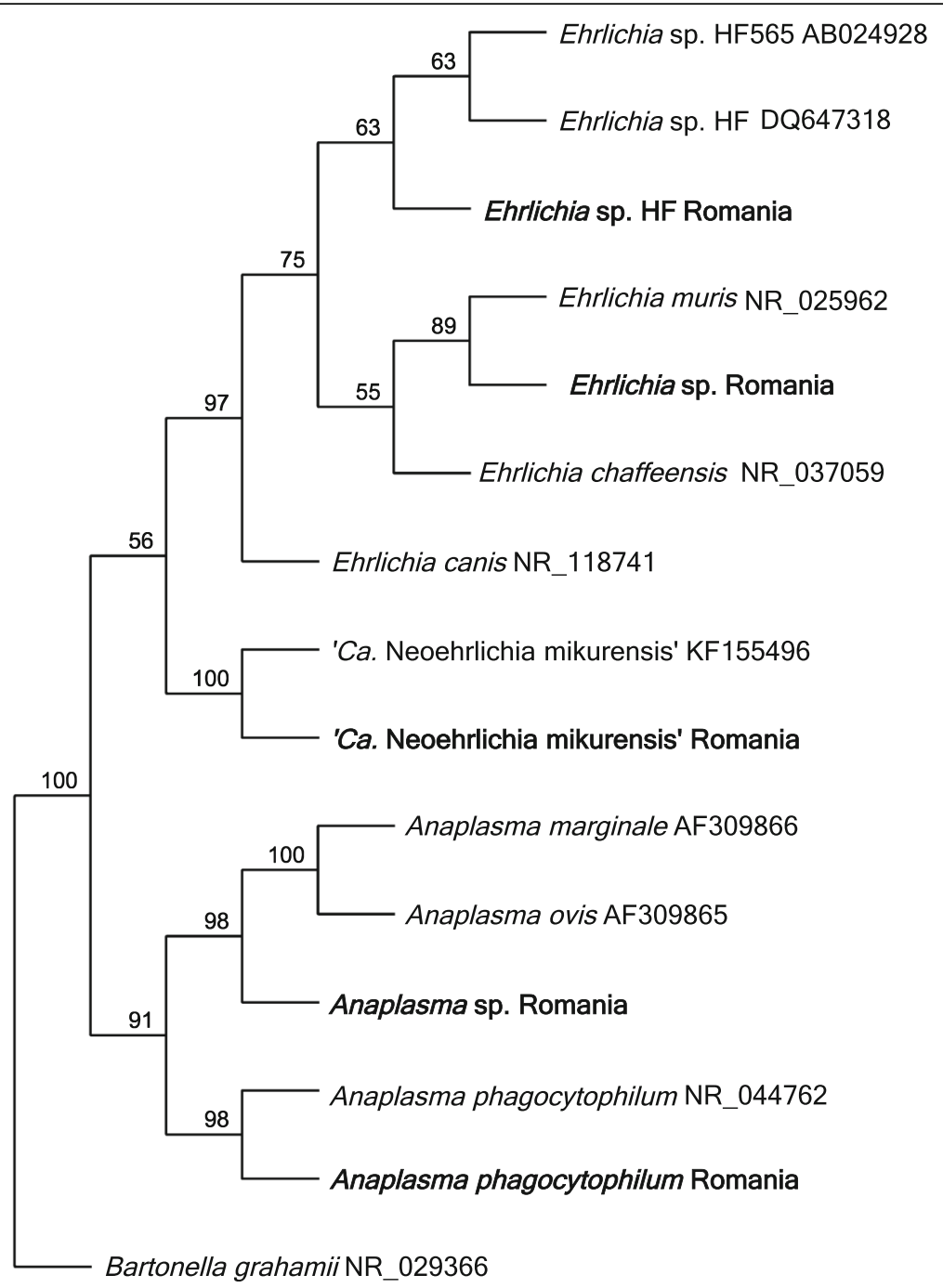

Fig. 4 Phylogenetic relationship between Anaplasma, Ehrlichia and "Ca. Neoehrlichia mikurensis" species. Neighbor-joining tree with Jukes-Cantor as genetic distance model. Sequences obtained in the current study are in bold. The tree is based on 139 nucleotide positions of the 165 ribosomal RNA gene

and $R$. slovaca [34], but also $R$. helvetica [31]. In Croatia, $R$. conorii, $R$. slovaca, $R$. helvetica and $R$. aeschlimannii have been detected in $R h$. sanguineus, D. marginatus and Hyalomma marginatum, respectively [31, 35].

In the present study, no $R$. conorii was detected. Nevertheless, the data discussed by Serban et al. [36] suggest a sporadic human infection in Constanta county and the authors conclusion that the distribution of cases matches with the distribution of $R$. conorii and its tick vectors, and also with the period of greatest activity of the vector $R h$. sanguineus, is not supported by the scientific data. Ionita et al. [37] reported one case of $R$. conorii, but without giving details about the place where the tick was collected. The same authors detected other Rickettsia spp. in ticks from Romania, e.g. R. raoultii (16\%) and R. slovaca (3\%) in D. reticulatus, and $R$. monacensis (11\%) in I. ricinus [37].
Marcutan et al. [38] reported the first individual records of different Rickettsia spp. in H. concinna ( $R$. monacensis), I. arboricola ( $R$. helvetica, $R$. massiliae) and I. redikorzevi ( $R$. helvetica) and also the first geographical record on the occurrence of $R$. massiliae in Romania, representing the easternmost observation in Europe. These results confirm earlier work on the geographical distribution of Rickettsia spp. in Romania, and increase our knowledge regarding the geographical distribution of these species. As most of the Rickettsia spp. identified and described here are known to cause human disease they should be considered in differential diagnosis of febrile or exanthematous clinical disease in Romanians, and in travelers from Romania.

The bacterial genus Bartonella contains several species of zoonotic concern. Bartonella vinsonii berkhoffii was first reported in a dog with endocarditis [16] and have 
been reported to cause human infection with arthralgia, fatigue and neurological symptoms in immunocompetent individuals [15]. Several strains of this subspecies have been described [39]. The strain Winnie, with a ssrA sequence identical to the one obtained from Romania in the current study, was originally isolated from a dog in USA [3]. In Romania, a large proportion of human patients diagnosed with haematologic cancer and undergoing chemotherapeutic treatment were shown to be seroreactive against Bartonella spp. antigens. This was especially common in patients living on farms with animal contact [40].

The presence of Ehrlichia sp. HF in four samples, all collected from dogs, is noteworthy. In Romania, this bacterium has previously been detected in I. apronophorus collected from dogs and a fox [41]. Prior to this report, Ehrlichia sp. HF had not been reported from Romania. Nevertheless, in the present study it was the most commonly detected Ehrlichia species. Nothing is known, so far, either on the transmission cycle or on the pathogenesis of this Ehrlichia species. The repeated detection, however, warrants further studies on this species potential role as a pathogen in dogs and perhaps humans.

A single case of an Ehrlichia sp. closely related to $E$. chaffeensis occurred in a tick collected from a fox. It is not possible to distinguish E. chaffeensis and E. muris based on the sequence fragment obtained in the current study. Nevertheless, the related canine pathogen E. canis differs by three nucleotides and can thus be readily differentiated. The occurrence of this Ehrlichia sp. requires further investigation with molecular methods in Romania.

"Candidatus N. mikurensis" was detected in an I. ricinus collected from a dog in north-eastern Romania. This species has been reported in I. ricinus from several counties in the western and central part of Romania [13, 14] and it seems widespread in the country. Infection with " $\mathrm{Ca}$. N. mikurensis" in a dog with chronic neutropenia has been reported in a single case from Germany [42]. A study investigating 96 dogs with suspected tick-borne infections from southern Romania did not show any case of infection with "Ca. N. mikurensis" [43]. The degree to which "Ca. N. mikurensis" can cause infection in dogs remains unclear. The relatively high prevalence in I. ricinus [44], the geographical widespread occurrence and the frequent exposure of dogs to questing ticks does nevertheless suggest that more studies need to be conducted on the subject.

The closely related Anaplasma species (A. marginale and $A$. ovis) could not be readily differentiated based on the partial $16 \mathrm{~S}$ rRNA fragment amplified in this study. The two species are closely related and differs at just a few positions in the complete $16 \mathrm{~S}$ rRNA gene. For example, the A. marginale strain 'Virginia', isolated from a cow in southern Virginia and A. ovis strain 'Idaho' isolated from a sheep, are $99.7 \%$ similar in the $16 \mathrm{~S}$ rRNA gene.
Three Rh. sanguineus "southeastern lineage" females were positive for Francisella spp. As the ticks were collected from dogs, it is possible that the ticks were infested with the bacterium either as a larva or nymph during previous feeding or during feeding as adults on the dog. Regardless of when the ticks were infected, this is the first detection of Francisella spp. in Rh. sanguineus "southeastern lineage" in Braila, Romania. Due to the low amount of DNA the species of Francisella was not identified. Rhipicephalus sanguineus and Rh. rossicus are known as wetland ticks in Romania, and especially $R h$. rossicus might have a role as a vector in the transmission of $F$. tularensis $[45,46]$. Another tick species, Ixodes apronophorus, is considered as a potential vector of $F$. tularensis [47]. All ticks positive for Francisella spp. in the present study were from the same dog pound. Tularemia may cause clinical symptoms in dogs, and the health consequences in the local dog pound could preferentially be further studied. Moreover, dogs may act as carrier of the pathogen across countries.

Nevertheless, Francisella-like endosymbionts of ticks are known and such organisms have been reported in various tick species from different countries: Haemaphysalis flava and $H$. phasiana in the Republic of Korea [48], Dermacentor reticulatus in Portugal [49], Bulgaria [50] and Hungary [51], Rh. sanguineus (s.l.) in Bulgaria [50] and Thailand [52], and in Hyalomma in Israel [53] and Bulgaria [50]. It was not detected in ticks investigated in Turkey [54].

\section{Conclusions}

A substantial diversity of bacterial tick-borne pathogens was observed when screening ticks collected from animal hosts in Romania. This diversity was especially evident by the number of different species and genotypes of Rickettsia detected. Some of the findings in this study are novel for Romania, such as the detection of the zoonotic Bartonella vinsonii berkhoffii in a tick collected from a dog. Three cases of Francisella spp. were found in Rh. sanguineus collected from dogs. Taken together the results presented in this study warrant further studies on the consequences of tick-borne pathogens in domestic animals in Romania.

\section{Additional file}

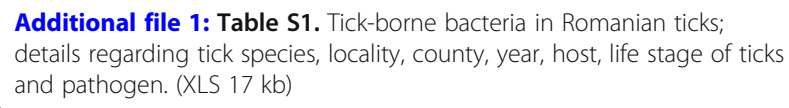

Acknowledgements

Publication of this paper has been sponsored by Bayer Animal Health in the framework of the 13th CVBD World Forum Symposium. 


\section{Funding}

MOA was supported by a grant from the Lawski foundation (Sven och Lilly Lawskis fond för naturvetenskaplig forskning). Laboratory work was funded by Bayer Animal Health. The funding sources had no role in the study design, in the collection, analysis and interpretation of data, or in the writing of the report.

\section{Availability of data and materials}

The datasets supporting the conclusions of this article are included within the article and its additional file. The sequences are submitted in the GenBank database under accession numbers: $R$. raoultii (MG450326 and MG450327); R. massiliae (MG450328); R. helvetica (MG450329); R. monacensis (MG450330 and MG450331); R. slovaca (MG450332); R. aeschlimannii (MG450333); B. vinsonii berkhoffii (MG432827).

\section{Authors' contributions}

MOA, LCD and GD planned and organized the study. PT, MS, GR and LCD collected ticks. LCD performed species identification of ticks, extracted DNA and tested for Rickettsia. HT tested for Francisella, DF tested for Coxiella and MOA tested for Anaplasma, Ehrlichia, Neoehrlichia, Bartonella and analyzed sequence data. MOA and LCD wrote the manuscript with input from CT, JW and GD. All authors read and approved the final manuscript.

\section{Ethics approval and consent to participate}

Not applicable.

\section{Consent for publication}

Not applicable.

\section{Competing interests}

The authors declare that they have no competing interests.

\section{Publisher's Note}

Springer Nature remains neutral with regard to jurisdictional claims in published maps and institutional affiliations.

\begin{abstract}
Author details
${ }^{1}$ Center for Ecology and Evolution in Microbial Model Systems (EEMiS), Linnaeus University, -391 82 Kalmar, SE, Sweden. ${ }^{2}$ Institute for Diagnosis and Animal Health, Bucharest, Romania. ${ }^{3}$ PAUMI-VET Private Veterinary Clinics, Ilfov County, Snagov, Romania. ${ }^{4}$ Sal-Vet Private Veterinary Clinics, Timis County, Timisoara, Romania. ${ }^{5}$ Bundeswehr Institute of Microbiology, Neuherbergstrasse 11, D-80937 Munich, Germany. ${ }^{6}$ Friedrich-Loeffler-Institut, Institute of Bacterial Infections and Zoonoses, Naumburger Strasse 96a, 07743 Jena, Germany. ${ }^{7}$ German Center of Infection Research (DZIF) Partner Munich, Neuherbergstrasse 11, D-80937 Munich, Germany.
\end{abstract}

Received: 15 November 2017 Accepted: 26 February 2018 Published online: 20 March 2018

\section{References}

1. Jones EH, Hinckley AF, Hook SA, Meek Jl, Backenson B, Kugeler KJ, et al. Pet ownership increases human risk of encountering ticks. Zoonoses Public Health. 2017:65:74-9.

2. Levin ML, Killmaster LF, Zemtsova GE. Domestic dogs (Canis familiaris) as reservoir hosts for Rickettsia conorii. Vector-Borne Zoonotic Dis. 2012;12:28-33.

3. Kordick DL, Breitschwerdt EB. Persistent infection of pets within a household with three Bartonella species. Emerg Infect. Dis. 1998;4:325-8

4. Raoult D, Roux V. Rickettsioses as paradigms of new or emerging infectious diseases. Clin Microbiol Rev. 1997;10:694-719.

5. Parola P, Paddock CD, Raoult D. Tick-borne rickettsioses around the world: emerging diseases challenging old concepts. Clin Microbiol Rev. 2005;18: 719-56.

6. Parola P, Paddock CD, Socolovschi C, Labruna MB, Mediannikov O, Kernif T, et al. Update on tick-borne rickettsioses around the world: a geographic approach. Clin Microbiol Rev. 2013;26:657-702

7. Novakova M, Vichova B. Granulocytic anaplasmosis - emerging tick-borne disease of humans and animals. Biologia (Bratisl). 2010;65:925-31.

8. Dumler JS, Barbet AF, Bekker CP, Dasch GA, Palmer GH, Ray SC, et al. Reorganization of genera in the families Rickettsiaceae and Anaplasmataceae in the order Rickettsiales: unification of some species of Ehrlichia with Anaplasma,
Cowdria with Ehrlichia and Ehrlichia with Neorickettsia, descriptions of six new species combinations and designation of Ehrlichia equi and 'HGE agent' as subjective synonyms of Ehrlichia phagocytophila. Int J Syst Evol Microbiol. 2001; 51:2145-65.

9. Ionita M, Mitrea IL, Pfister K, Hamel D, Silaghi C. Molecular evidence for bacterial and protozoan pathogens in hard ticks from Romania. Vet Parasitol. 2013;196:71-6.

10. Matei IA, Kalmár Z, Magdas C, Magdas V, Toriay H, Dumitrache MO, et al. Anaplasma phagocytophilum in questing Ixodes ricinus ticks from Romania. Ticks Tick Borne Dis. 2015;6:408-13.

11. Matei IA, Ionica AM, D'Amico G, Corduneanu A, Daskalaki AA, Lefkaditis M, et al. Altitude-dependent prevalence of canine granulocytic anaplasmosis in Romania. Vector Borne Zoonotic Dis. 2017:17:147-51.

12. Andersson M, Turcitu MA, Stefanache M, Tamba P, Barbuceanu F, Chitimia L. First evidence of Anaplasma platys and Hepatozoon canis co-infection in a dog from Romania - a case report. Ticks Tick Borne Dis. 2013;4:317-9.

13. Andersson M, Zaghdoudi-Allan N, Tamba P, Stefanache M, Chitimia L. Coinfection with "Candidatus Neoehrlichia mikurensis" and Borrelia afzelii in an Ixodes ricinus tick that has bitten a human in Romania. Ticks Tick Borne Dis. 2014;5:706-8

14. Kalmár Z, Sprong H, Mihalca AD, Gherman CM, Dumitrache MO, Coipan EC et al. Borrelia miyamotoi and "Candidatus Neoehrlichia mikurensis" in Ixodes ricinus Ticks, Romania. Emerg Infect Dis. 2016;22:550-1.

15. Breitschwerdt EB, Maggi RG, Lantos PM, Woods CW, Hegarty BC, Bradley JM. Bartonella vinsonii subsp. berkhoffii and Bartonella henselae bacteremia in a father and daughter with neurological disease. Parasit Vectors. 2010;3:29.

16. Breitschwerdt EB, Kordick DL, Malarkey DE, Keene B, Hadfield TL, Wilson K. Endocarditis in a dog due to infection with a novel Bartonella subspecies. J Clin Microbiol. 1995;33:154-60.

17. Estrada-Peña A, Bouattour A, Camicas J, Walker AR. Ticks of domestic animals in the Mediterranean Region: A guide to identification of species. Zaragoza: University of Zaragoza: International Consortium on Ticks and Tick-Borne Diseases (ICTTD-2); 2004

18. Feider Z. [Fauna of the Popular Republic of Romania. Volume 5/2. Acaromorpha, Suprafamily Ixodoidea]. Bucharest: Academiei Republicii Populare Romane; 1965. (In Romanian).

19. Chitimia-Dobler L, Langguth J, Pfeffer M, Kattner S, Küpper T, Friese D, et al. Genetic analysis of Rhipicephalus sanguineus sensu lato ticks parasites of dogs in Africa north of the Sahara based on mitochondrial DNA sequences. Vet Parasitol. 2017;239:1-6.

20. Wölfel R, Essbauer S, Dobler G. Diagnostics of tick-borne rickettsioses in Germany: A modern concept for a neglected disease. Int J Med Microbiol. 2008:298:368-74

21. Chitimia-Dobler L, Dobler G, Schaper S, Küpper T, Kattner S, Wölfel S. First detection of Rickettsia conorii ssp. caspia in Rhipicephalus sanguineus in Zambia. Parasitol Res. 2017;116:3249-51.

22. Krücken J, Schreiber C, Maaz D, Kohn M, Demeler J, Beck S, et al. A novel high-resolution melt PCR assay discriminates Anaplasma phagocytophilum and "Candidatus Neoehrlichia mikurensis". J Clin Microbiol. 2013:51:1958-61.

23. Andersson MO, Víchová B, Tolf C, Krzyzanowska S, Waldenström J, Karlsson ME. Co-infection with Babesia divergens and Anaplasma phagocytophilum in cattle (Bos taurus), Sweden. Ticks Tick Borne Dis. 2017;8:933-5.

24. Diaz MH, Bai Y, Malania L, Winchell JM, Kosoy MY. Development of a novel genus-specific real-time PCR assay for detection and differentiation of Bartonella species and genotypes. J Clin Microbiol. 2012;50:1645-9.

25. Versage $\mathrm{J}$, Severin DDM, Chu MC, Petersen MJ. Development of a multitarget real-time TagMan PCR assay for enhanced detection of Francisella tularensis in complex specimens. J Clin Microbiol. 2003;(12):5492-9.

26. Frangoulidis D, Meyer $H$, Kahlhofer C, Splettstoesser WD. "Real-time" PCRbased detection of Coxiella burnetii using conventional techniques. FEMS Immunol Med Microbiol. 2011;64:134-6.

27. Al-Deeb MA, Frangoulidis D, Walter MC, Kömpf D, Fischer SF, Petney TN, et al. Coxiella-like endosymbiont in argasid ticks (Ornithodoros muesebecki) from a Socotra Cormorant colony in Umm Al Quwain, United Arab Emirates. Ticks Tick Borne Dis. 2016;7:166-71.

28. Burgdorfer W, Aeschlimann A, Péter O, Hayes SF, Philip RN. Ixodes ricinus: vector of a hitherto undescribed spotted fever group agent in Switzerland. Acta Trop. 1979:36:357-67

29. Beati L, Peter O, Burgdorfer W, Aeschlimann A, Raoult D. Confirmation that Rickettsia helvetica sp. nov. is a distinct species of the spotted fever group of rickettsiae. Int J Syst Bacteriol. 1993:43:521-6. 
30. Dautel H, Dippel C, Oehme R, Hartelt K, Schettler E. Evidence for an increased geographical distribution of Dermacentor reticulatus in Germany and detection of Rickettsia sp. RpA4. Int J Med Microbiol. 2006;296:149-56.

31. Dobec M, Golubic D, Punda-Polic V, Kaeppeli F, Sievers M. Rickettsia helvetica in Dermacentor reticulatus ticks. Emerg Infect Dis. 2009;15:98-100.

32. Reye AL, Stegniy V, Mishaeva NP, Velhin S, Hübschen JM, Ignatyev G, et al. Prevalence of tick-borne pathogens in Ixodes ricinus and Dermacentor reticulatus ticks from different geographical locations in Belarus. PLoS One. 2013;8:14-6.

33. Wojcik-Fatla A, Cisak E, Zajac V, Sroka J, Sawczyn A, Dutkiewicz J. Study on tick-borne rickettsiae in eastern Poland. I. Prevalence in Dermacentor reticulatus (Acari: Amblyommidae). Ann Agric Environ Med. 2013;20:276-9.

34. Špitalská E, Štefanidesová K, Kocianová E, Boldiš V. Rickettsia slovaca and Rickettsia raoultii in Dermacentor marginatus and Dermacentor reticulatus ticks from Slovak Republic. Exp Appl Acarol. 2012;57:189-97.

35. Punda-Polic V, Petrovec M, Trilar T, Duh D, Bradari N, Detection KZ. Identification of spotted fever group rickettsiae in ticks collected in southern Croatia. Exp Appl Acarol. 2002;28:169-76.

36. Serban R, Pistol A, Negut M, Cucuiu R. Rickettsia conorii infection in Romania. Bacteriol Virusol Parazitol Epidemiol. (Bucur). 2009;54:177-83.

37. Ionita M, Silaghi C, Mitrea IL, Edouard S, Parola P, Pfister K. Molecular detection of Rickettsia conorii and other zoonotic spotted fever group rickettsiae in ticks, Romania. Ticks Tick Borne Dis. 2016;7:150-3.

38. Mărcuțan I-D, Kalmár Z, Ionică AM, D'Amico G, Mihalca AD, Vasile C, et al. Spotted fever group rickettsiae in ticks of migratory birds in Romania. Parasit Vectors. 2016;9:294.

39. Maggi RG, Chomel B, Hegarty BC, Henn J, Breitschwerdt EB. A Bartonella vinsonii berkhoffii typing scheme based upon 16S-23S ITS and Pap31 sequences from dog, coyote, gray fox, and human isolates. Mol Cell Probes. 2006;20:128-34

40. Messinger CJ, Gurzau ES, Breitschwerdt EB, Tomuleasa CI, Trufan SJ, Flonta MM, et al. Seroprevalence of Bartonella species, Coxiella burnetii and Toxoplasma gondii among patients with hematological malignancies: A pilot study in Romania. Zoonoses Public Health. 2017;64:485-90.

41. Andersson MO, Radbea G, Frangoulidis D, Tomaso H, Rubel F, Nava S, Chitimia-Dobler L. New records and host associations of the tick Ixodes apronophorus and the first detection of Ehrlichia sp. HF in Romania. Parasitol Res. 2018; https://doi.org/10.1007/s00436-018-5800-3.

42. Diniz PPVP, Schulz BS, Hartmann K, Breitschwerdt EB. "Candidatus Neoehrlichia mikurensis" infection in a dog from Germany. J Clin Microbiol. 2011:49:2059-62.

43. Andersson MO, Tolf C, Tamba P, Stefanache M, Waldenström J, Dobler G, et al. Canine tick-borne diseases in pet dogs from Romania. Parasit Vectors. 2017;10:155

44. Richter D, Matuschka F-R. "Candidatus Neoehrlichia mikurensis", Anaplasma phagocytophilum and Lyme disease spirochetes in questing European vector ticks and in feeding ticks removed from people. J Clin Microbiol. 2012:50:943-7.

45. Mihalca AD, Dumitrache MO, Magdaş C, Gherman CM, Domşa C, Mircean V, et al. Synopsis of the hard ticks (Acari: Ixodidae) of Romania with update on host associations and geographical distribution. Exp Appl Acarol. 2012;58: 183-206.

46. Sandor AD, Dumitrache MO, D'Amico G, Kiss BJ, Mihalca AD. Rhipicephalus rossicus and not $R$. sanguineus is the dominant tick species of dogs in the wetlands of the Danube Delta, Romania. Vet Parasitol. 2014;204:430-2.

47. Eichler W. Kritische Liste mitteleuropäischer Zeckenarten. Angew Parasitol. 1968;9:88-97.

48. Takhampunya R, Kim HC, Chong ST, Korkusol A, Tippayachai B, Davidson SA, et al. Francisella-like endosymbiont detected in Haemaphysalis ticks (Acari: Ixodidae) from the Republic of Korea. J Med Entomol. 2017;54:1735-42.

49. de Carvalho I, Santos N, Soares T, Zé-Zé L, Núncio MS. Francisella-like endosymbiont in Dermacentor reticulatus collected in Portugal. Vector-Borne Zoonotic Dis. 2010;11:185-188.

50. Ivanov IN, Mitkova N, Reye AL, Hübschen JM, Vatcheva-Dobrevska RS, Dobreva EG, et al. Detection of new Francisella-like tick endosymbionts in Hyalomma spp. and Rhipicephalus spp. (Acari: Ixodidae) from Bulgaria. Appl Environ Microbiol. 2011;77:5562-5.

51. Kreizinger Z, Hornok S, Dán A, Hresko S, Makrai L, Magyar T, et al. Prevalence of Francisella tularensis and Francisella-like endosymbionts in the tick population of Hungary and the genetic variability of Francisella-like agents. Vector-Borne Zoonotic Dis. 2013;13(3):160.
52. Rakthong P, Ruang-Areerate T, Baimai V, Trinachartvanit W, Ahantarig A. Francisella-like endosymbiont in a tick collected from a chicken in southern Thailand. Southeast Asian J Trop Med Public Health. 2016;47:245-9.

53. Azagi T, Klement E, Perlman G, Lustig Y, Mumcuoglu KY, Apanaskevich DA, et al. Francisella-like endosymbionts and Rickettsia species in local and imported Hyalomma ticks. Appl Environ Microbiol. 2017;31:18.

54. Duzlu O, Yildirim A, Inci A, Gumussoy KS, Ciloglu A, Onder Z. Molecular investigation of Francisella-like endosymbiont in ticks and Francisella tularensis in ixodid ticks and mosquitoes in Turkey. Vector-Borne Zoonotic Dis. 2016;16:26-32.

\section{Submit your next manuscript to BioMed Central and we will help you at every step:}

- We accept pre-submission inquiries

- Our selector tool helps you to find the most relevant journal

- We provide round the clock customer support

- Convenient online submission

- Thorough peer review

- Inclusion in PubMed and all major indexing services

- Maximum visibility for your research

Submit your manuscript at www.biomedcentral.com/submit
) Biomed Central 